\title{
対立の弁証法的解決に向けた妥協的推論の形式化 Formalizing Reasoning for Compromise toward Dialectical Conflict Resolution
}

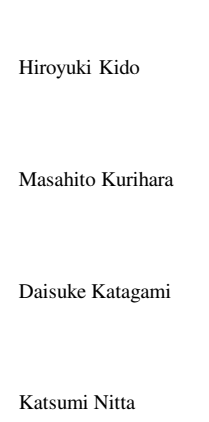

\author{
東京工業大学 大学院総合理工学研究科 \\ Interdisciplinary Graduate School of Science and Engineering, Tokyo Institute of Technology, Japan \\ kidoentt.dis.titech.ac.jp \\ 北海道大学 大学院情報科学研究科 \\ Graduate School of Information Science and Technology, Hokkaido University, Japan \\ kurihara@ist.hokudai.ac.jp, http://kussharo.complex.eng.hokudai.ac.jp/ kurihara/ \\ 東京工業大学 大学院総合理工学研究科 \\ Interdisciplinary Graduate School of Science and Engineering, Tokyo Institute of Technology, Japan \\ katagamientt.dis.titech.ac.jp, http://www.ntt.dis.titech.ac.jp/home/katagami/ \\ (同上) \\ nitta@dis.titech.ac.jp, http://www.ntt.dis.titech.ac.jp/home/nitta/
}

keywords: argumentation, compromise, dialectical thought, negotiation

\begin{abstract}
Summary
Argumentation in artificial intelligence, often called computational dialectics, is rooted in Aristotle's idea of evaluating argumentation in a dialogue model. In contrast, Chinese traditional philosophy regards dialectics as a style of reasoning that focuses on contradictions and how to resolve them, transcend them or find the truth in both. A compromise is considered one way to resolve conflicts dialectically. In this paper, we formalize reasoning intended to derive a compromise. Both the reasoning and the compromise are defined on abstract lattices procedurally and declaratively, respectively. We prove that the reasoning is sound and complete with respect to the compromise. Then we define the concrete and sound algorithm for the reasoning on the lattice characterized by definite clausal language and generalized subsumption. Under some conditions, the reasoning offers a unified way to reason rationally whether a set of the premises is consistent or not. Such reasoning is outside the scope of logics that have the principle of explosion. Further, the compromise has a unique logical setting compared with other types of reasoning such as deduction, induction, and abduction. We incorporate the reasoning into arguments, and illustrate that the use of arguments with compromise contributes to realizing a compromise-based conflict resolution in argumentation.
\end{abstract}

\section{1. は じめに}

近年 , 交渉や実践推論を撤回可能議論 (以後 , 議論と呼 ぶ）に基づいて形式化する試みか数多く存在する [Kowalski 94, Rahwan 05, Bench-Capon 06, Wells 06, Amgoud 08, Dung 08, Modgil 09] . 議論の特徵の一つは , 推論の 非単調性と種々の推論の型を切り離して形式的に扱うこ とができる点にある . 我々の交渉などでは , 新たな主張に よりこれまでの主張が覆るといった状況が多々生じ，ま た目的から手段の考察や事例の一般化などが行われる. 論理学的にはこの前者の性質は推論の非単調性といわれ， 後者の性質は種々の推論の型といわれる . 議論は内部構 造が規定されていない論証の相互作用に基づいて，論証 を最小単位とした非単調性を実現するため, 論証の内部 で使われる推論は非単調性を持つ必要がない．この理由 から議論では種々の推論の型が扱いやすい .

計算機科学における議論研究は, 対話的な方法で論証 の正しさを評価するというアリストテレスの弁証法に対 する考え方に起源を持つことから，計算弁証法と呼ばれ
ている [Walton 08] .一方 , 弁証法という言葉は关の時々 の哲学者によって色々な意味で使われてきており，光れと は異なる定義や解釈も存在している. 事実, ある心理学 者は弁証法を妥協や中庸を求める推論樣式 [Nisbett 03] と みなし，ある論理学者は矛盾律を排除した体系 [Carnielli 07]とみなしている . Nisbett は, 弁証法とは矛盾に注目 し, 弚れをいかに解決あるいは超越するか，もしくは両 方において何らかの真実を見出すことに注目する推論樣 式であると述べている.さらに対立する命題への対処法 の違いとして, 西洋人に多い論理的な方法と東洋人に多 い弁証法的な方法を比較している．乥こでは論理的な方 法は矛盾を避けるために一方の命題を受け入れ, 他方を 拒絶すると説明され, 弁証法的な方法は中庸を目指し両 方において何らかの真実を見出すことを好むと説明され る. 光して弁証法的な方法は問題の原因が両者にあると 考え, 妥協や超越によって対立する見解を調整しようと 試みるものであるとされる .この指摘はアリストテレス に起源を持つ議論研究の発展においても重要である . な ぜなら議論や対話は社会的意思決定や合意形成の有力な 
手段であり，ここでいう弁証法的な考え方のない社会的 意思決定や合意形成は皆無だからである．

この観点から既存の議論研究を見るとき, 弁証法的な対 立の解決というものを目指したものは少ない . [Amgoud 08] において著者は議論に基づく交渉の抽象的フレーム ワークを与え，交渉において必須の概念として「譲歩」 を導入している.しかし，これは所与の提案のうち議論 に基づく評価により準最適とみなされた提案のことを指 し，推論によって導出されるものではない . [Sawamura 03]において著者は，へーゲルの弁証法といわれるもの のうち矛盾の許容, 否定の否定の法則を形式的論理とし て捉えることを試みた DL, DM [Mitroff 82] に対して，7 つの弁証法的推論規則を導入し，譲歩や妥協として矛盾 からの合理的推論を実現している.しかし，7 つの推論 は光れを支配する統一的基準が示されておらず，また哲 学的知見 [Sabre 91] に反して推論の前提が矛盾に限定さ れている。

本稿では多義的な弁証法に対して㚇の一般性を論じる など深遠な内容に立入ることはしない，本稿では対立に 対する弁証法的な方法の一つの在り方である妥協に注目 する. 弚して妥協を推論する推論法を提案し，本稿の議 論システムの下で光の推論か議論の対立の解決に有効で あることを例示する．本稿では妥協及び光の推論モデル を共に抽象的な束の上に定義し，弚のモデルの妥協に対 する健全性と完全性を示す．弚の後，確定節言語及び一般 化包摂を対象とした健全な推論のアルゴリズムを定義す る . 推論モデルの具体化としての推論は統一的基準の下 で推論の前提を矛盾に限定することなく妥協を推論する 推論結果は議論の特長に基づき論証に組み込まれ，弚の 論証の導入によって議論の対立が妥協的に解決されるこ とを例示する．

以下，2 章において動機となる妥協的思考を示す. 3 章 では推論の目標を形式化し，4 章では光の推論方式を与 える. 5 章では提案した推論を議論に組み込み，妥協的 議論を例示する.6 章において関連研究である既存の種々 の推論及び議論研究との対比を述べ, 7 章において結論 と今後の課題を述べる.

\section{2. 妥 協 的 思 考}

本章では研究の動機となる妥協的な思考を示す．今，二 人のエージェント $A, B$ が互いにお金を出し合い一台の カメラを購入する状況を考える . 各エージェントは光れ

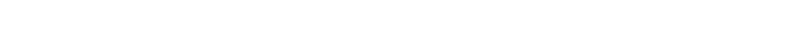
に対立しているとする .

$A ：$ コンパクトで軽いカメラ $a$ を買いたい .

$B$ ： 弚れは品切れ中のようです.

$B$ ： 高画質でバッテリの持ちが良いカメラ $b$ を買いたい . $A ：$ 弚れは予算を超えています。

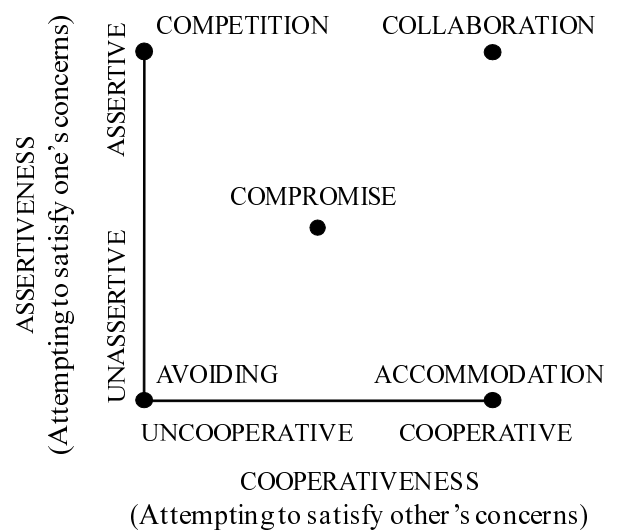

図 1 Two-dimensional taxonomy of conflict handling modes [Thomas 92]

この状況において， $A$ によるカメラ $a$ の提案及び $B$ によ るカメラ $b$ の提案のいずれも相手からの反論を受けてい る. 弚して $A, B$ は乥の反論を退けることができていな い.より形式的に言えば，各カメラ $a, b$ の購入を支持す る論証は議論意味論の下で正当化 (justified) されない . 今， $A, B$ のいずれも別のカメラの購入を支持する論証を 作ることができないか，または作れたとしても反論を退 けることができない状況を考える . このときどのカメラ を購入するかということに関して議論は物別れに終わる ことになる，一方，我々はこのような状況において日常 的に妥協という問題対処方法を用いることで議論や対話 を進める . 例えば次の展開を考える .

$A ：$ 弚れでは,(コンパクトで軽ければお光らく使いやす (ので) 使いやすくてバッテリの持ちが良いカメラ cにしますか

$B$ ：㫕うですね.

$A$ の観点においてカメラ $c$ は, カメラ $a$ の持つコンパク 卜で軽いという属性を持たないものの，光れらが成立す る結果成り立つ使いやすいという属性を保持する。他方， $B$ の観点においてカメラ $c$ は, カメラ $b$ の持つ高画質で バッテリの持ちが良いという両方の属性は持たないもの の，後者の属性を保持する.すなわち , カメラ $c$ の購入 の提案は, カメラ $a$ の購入を提案したエージェント $A$ と カメラ $b$ の購入を提案したエージェント $B$ の意向を完全 にではなく一部ずつ反映している．本稿では，カメラ $c$ において見られる妥協的な考え方を形式的かつ論理的な 推論として実現する。

\section{3. 意 味 論}

推論を定義する前に，弚の推論の目標を形式的に明確 化する.これは光の推論が導出しようとする対象を明ら かにするためだけでなく，6.1 節において他の推論との 差異を明らかにするために重要となる．本章では推論の 目標である「妥協」及び「協調的妥協」の判定式を定義 することで觉の評価方法を与える . 


\section{$3 \cdot 1$ 妥 協}

[Thomas 92] は我々の対立への対処法を图 1 に示す $5 つ$ に分類している . 図の縦軸は自身の関心に対する主張の強 さを表し，横軸は相手の関心に対する協調の強さを表す． 競合 (competition), 協同 (collaboration), 回避 (avoiding)， 順応 (accommodation) は乥れ光れ図の左上, 右上, 左下, 右下に位置し, 妥協 (compromise) は図の中央に位置す る. 図より妥協は，協同とは異なり両者の意向がどちら も完全に反映されるものであってはならず，回避とも異 なりどちらも完全に反映されないものであってもならな い. また，競合と順応とも異なり，両者のうち一方のみが 完全に反映され，他方が完全に反映されないものであっ てもならない，本稿では，両者の意向が両方とも完全に 反映されることはなく，両者の意向が少なくとも一部ず つ反映されていることを兰れ光れ不十分性，関連性と呼 び, この二つの条件が妥協の必要十分条件であるとみな す．光して言語及び光の上の順序関係が未規定である抽 象的な束の上に妥協を形式的に定義する。

【定義 1】(妥協) $<\mathcal{L}, \succeq>$ を束 $, X_{1}, \ldots, X_{n} \in \mathcal{L}$ とす る. 次の条件が成立するとき, $Y$ は $X_{1}, \ldots, X_{n}$ の間の妥 協である。

(1) 不十分性 : $\forall X_{i}\left(Y \nsucceq X_{i}\right)$

(2) 関連性 : $\forall X_{i}\left(\inf \left\{X_{i}, Y\right\} \nsim \top\right)$

$X, Y \in \mathcal{L}$ に対して $X, Y$ を弚れ要素と呼び， $X \succeq$ $Y$ が成立することを $X$ は $Y$ の上位または $Y$ は $X$ の下 位であるという . また $X \succeq Y$ かつ $Y \succeq X$ が成立するこ とを $X \sim Y$ で表記する . 定義 1 における不十分性の条 件は, 妥協である $Y$ は任意の $X_{i}$ のいずれの上位でもな いことを要求し，関連性の条件は各 $X_{i}$ に対して， $Y, X_{i}$ の両方の下位である非空の要素が存在することを要求す る. 全順序で表される価格の定量的な妥協，半順序で表 される集合の包含関係に基づく定性的な妥協などが具体 化として表現される．本稿では特に，論理的観点におけ る妥協に注目する.

〔 例 1]（命題論理上の妥協） $\mathcal{L}$ をアルファベット $A, B$ から構成されるすべての整論理式からなる言語，トを充 足関係とする . 図 2 は $<\mathcal{L}, \vDash>$ が形成する束である . 定 義 1 は次式で具体化される.

(1) 不十分性 : $\forall X_{i}\left(\{Y\} \not \models X_{i}\right)$

(2) 関連性 : $\forall X_{i}\left(\nvdash X_{i} \vee Y\right)$

$X \vDash Y$ かつ $Y \vDash X$ が成り立つことを $X \equiv Y$ で表記す る . 次の (i), (ii) において $Y$ は $X_{1}, X_{2}$ の間の妥協である .

(i) $X_{1} \equiv \neg A \wedge B, X_{2} \equiv A, Y \equiv B$

(ii) $X_{1} \equiv \neg A \wedge B, X_{2} \equiv A, Y \equiv \neg B$

\section{$3 \cdot 2$ 協 調 的 妥協}

我々は定義 1 において形式的に妥協を定義した．しか し定義 1 は直感的に妥協とは呼び難いものを妥協とみな す . 例 1 の (ii) は光の一例である . (ii) では $X_{1}$ の下位で ある $\neg A \vee \neg B$ は $Y$ の下位（すなわち， $X_{1}$ からの意味

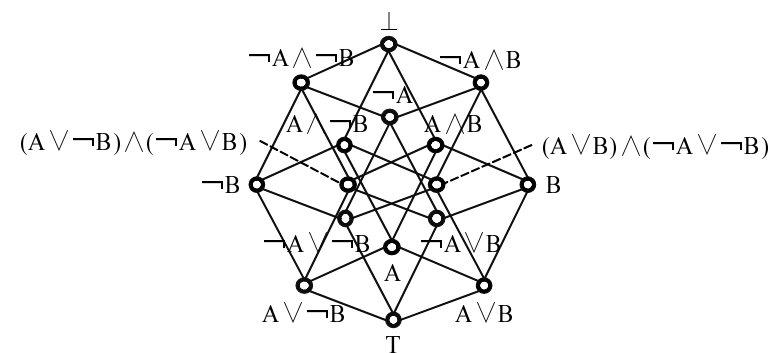

図 $2<\mathcal{L}, \vDash>$ が形成する束

論的帰結である $\neg A \vee \neg B$ は $Y$ からの意味論的帰結) で あり， $X_{2}$ の下位である $A \vee \neg B$ は $Y$ の下位であり，光 のいずれも恒真式でないことから関連性を満たす．しか し，妥協 $Y$ は $X_{1}$ と $X_{2}$ の共通の下位である $A \vee B$ の 上位ではなく, 图 1 の意味での協調性 (cooperativeness) に欠ける. また， $X_{1}=A \wedge B, X_{2}=B \wedge C, Y=B \wedge D$ とするとき， $Y$ は $X_{1}, X_{2}$ の間の妥協である . しかし,$D$ は $X_{1}, X_{2}$ との関連性という観点からは必要のない要素 であり，いわば $Y$ は簡潔性に欠ける .ここで指摘した協 調性と簡潔性の欠如に対処するために，妥協に対してい くつかの現実的な条件を加えた協調的妥協を定義する．

【定義 2】（協調的妥協） $<\mathcal{L}, \succeq>$ を束 $, X_{1}, \ldots, X_{n}, Y$ を $\inf \left\{X_{i} \mid 1 \leq i \leq n\right\} \nsim 丁$ を満たす $\mathcal{L}$ の元とする . 次 の条件が成立するとき， $Y$ は $X_{1}, \ldots, X_{n}$ の間の協調的妥 協である。

(1) 不十分性 : $\forall X_{i}\left(Y \nsucceq X_{i}\right)$

(2) 関連性 : $\forall X_{i}\left(\inf \left\{X_{i}, Y\right\} \nsim \top\right)$

(3) 協調性: $Y \succeq \inf \left\{X_{j} \mid 1 \leq j \leq n\right\}$

(4) 簡潔性 : $Y \sim \sup \left\{\inf \left\{X_{i}, Y\right\} \mid 1 \leq i \leq n\right\}$

定義 2 では, 定義 1 の条件に加えて協調性と簡潔性が 考慮される . 協調性は任意の $X_{i}$ の共通の下位の要素が, 妥協である $Y$ の下位となることを要求し，簡潔性は各 $X_{i}$ の下位の要素だけを妥協である $Y$ は下位とすること を要求する . 所与の $X_{1}, \ldots, X_{n}$ から実際に兰れらの間の 協調的妥協を導出する手続きは定義 3 で与えられる. 光 の手続きは, 束上で各 $X_{i}(1 \leq i \leq n)$ の下位の要素を計 算し, 弚れらの共通の上位の要素を計算することで協調 的妥協を導出する.

〔 例 2]（命題論理上の協調的妥協） $\mathcal{L}$ を命題言語， $\vDash$ を充足関係とするとき $<\mathcal{L}, \vDash>$ は束となる $. X_{1}, \ldots, X_{n}, Y$ を $X_{1} \vee \cdots \vee X_{n} \neq \equiv$ 丁を満たす $\mathcal{L}$ の元とするとき，定義 2 は次式で具体化される .

(1) 不十分性 : $\forall X_{i}\left(\{Y\} \not \models X_{i}\right)$

(2) 関連性: $\forall X_{i}\left(\not \models X_{i} \vee Y\right)$

(3) 協調性 : $Y \vDash X_{1} \vee \cdots \vee X_{n}$

(4) 簡潔性 : $\vDash Y \leftrightarrow\left(X_{1} \vee Y\right) \wedge \cdots \wedge\left(X_{n} \vee Y\right)$

このとき，例 1 における (i) は協調的妥協であり，(ii) は 協調的妥協ではない.

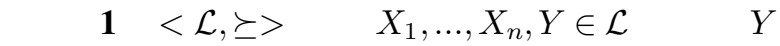
が $X_{1}, \ldots, X_{n}$ の間の協調的妥協であるならば， $Y$ は $X_{1}, \ldots$, 


\section{$X_{n}$ の間の妥協である .}

\section{4. 推 論 方 式}

前章では妥協及び協調的妥協の定義を与えた．本章で は実際に前提から協調的妥協を導く推論モデルと光の一 つの具体化である推論アルゴリズムを定義することで， 協調的妥協の構成方法を与える。

\section{$4 \cdot 1$ 協調的妥協の推論モデル}

協調的妥協は抽象的な束上に定義された . 従い，推論 モデルもまた抽象的な束上に定義する . 推論モデルは, 具 体的な束上で展開される個々の推論が従う推論の指針を 抽象的な束上に与える。

【定義 3】（推論モデル） $<\mathcal{L}, \succeq>$ を束， $X_{1}, \ldots, X_{n} \in$ $\mathcal{L}$ とする . 推論モデルは下記の手続きからなる .

(1) 任意の $X_{i}$ に対して, $X_{i}^{\prime} \nsim \top$ かつ $X_{i}^{\prime} \succeq \inf \left\{X_{j} \mid\right.$ $1 \leq j \leq n\}$ を満たす $X_{i}^{\prime} \preceq X_{i}$ を計算する.

（2）任意の $X_{i}$ に対して， $Y \nsucceq X_{i}$ を満たす $Y \sim \sup \left\{X_{i}^{\prime}\right.$ $\mid 1 \leq i \leq n\}$ を計算する .

所与の $X_{1}, \ldots, X_{n}$ に対して推論モデルの計算結果とし て認められるものからなる集合を $\mathcal{P}_{X_{1}, \ldots, X_{n}}$ と表記する. 推論モデルか持つ重要な性質として，協調的妥協に関す る健全性と完全性がある。

[ 定理 1]（協調的妥協に対する健全性と完全性） $<\mathcal{L}$, $\succeq>$ を束， $X_{1}, \ldots, X_{n} \in \mathcal{L}$ とする.$Y \in \mathcal{P}_{X_{1}, \ldots, X_{n}}$ であ るとき，かつ光のときに限り， $Y$ は $X_{1}, \ldots, X_{n}$ の間の協 調的妥協である。

《証明》 健全性を示す. 定義 3 より, $Y \in \mathcal{P}_{X_{1}, \ldots, X_{n}}$ な らは明らかに協調的妥協の不十分性が成立する . また $Y \in$ $\mathcal{P}_{X_{1}, \ldots, X_{n}}$ ならば任意の $X_{i}(1 \leq i \leq n)$ に対して $X_{i}^{\prime} \nsim$ $\top, X_{i}^{\prime} \succeq \inf \left\{X_{j} \mid 1 \leq j \leq n\right\}, X_{i} \succeq X_{i}^{\prime}$ かつ $Y \sim \sup \left\{X_{i}^{\prime}\right.$ $\mid 1 \leq i \leq n\}$ を満たす $X_{i}^{\prime}$ か存在する.今これを $X_{i}^{*}$ と置 〈. $X_{i} \succeq X_{i}^{*}, Y \succeq X_{i}^{*}$ より $\inf \left\{X_{i}, Y\right\} \succeq X_{i}^{*}$ が成立し， $X_{i}^{*} \nsim \top$ なので $\inf \left\{X_{i}, Y\right\} \nsim 丁$ が成立する.内えに関 連性が成り立つ. $\inf \left\{X_{i}, Y\right\} \succeq X_{i}^{*} ，$ かつ $X_{i}^{*} \succeq \inf \left\{X_{j} \mid\right.$ $1 \leq j \leq n\}$ が成立するので, $\inf \left\{X_{i}, Y\right\} \succeq \inf \left\{X_{j} \mid 1 \leq\right.$ $j \leq n\}$ が成立し，また $Y \succeq \inf \left\{X_{i}, Y\right\}$ であるから協調 性が成り立つ. また任意の $i$ に対して $Y \succeq \inf \left\{X_{i}, Y\right\}$ より $Y \succeq \sup \left\{\inf \left\{X_{i}, Y\right\} \mid 1 \leq i \leq n\right\}$ が成立する.ま た $Y \sim \sup \left\{X_{1}^{*}, \ldots, X_{n}^{*}\right\}$ であり，かつ任意の $i$ に対し て $\inf \left\{X_{i}, Y\right\} \succeq X_{i}^{*}$ であるから,$Y \preceq \sup \left\{\inf \left\{X_{i}, Y\right\} \mid\right.$ $1 \leq i \leq n\}$ が成立する．ゆえに簡潔性が成立する．

次に完全性を示す.定義 3 より， $Y$ が $X_{i}(1 \leq i \leq n)$ の 間の協調的妥協ならば(1) 任意の $X_{i}$ に関して,$Y \nsucceq X_{i}$ が 成立すること，かつ (2) $X_{i}^{\prime} \nsim \top, X_{i}^{\prime} \succeq \inf \left\{X_{j} \mid 1 \leq j \leq\right.$ $n\}, X_{i} \succeq X_{i}^{\prime}, Y \sim \sup \left\{X_{i}^{\prime} \mid 1 \leq i \leq n\right\}$ を満たす $X_{i}^{\prime}(1 \leq$ $i \leq n)$ が少なくとも一組存在することを示せば十分であ る.協調的妥協の不十分性より，(1) が成立する。ここで $X_{i}^{\prime} \sim \inf \left\{X_{i}, Y\right\}$ とする. 協調性より $Y \succeq \inf \left\{X_{i} \mid 1 \leq\right.$ $i \leq n\}$ が成立するから，ゆえに任意の $j(1 \leq j \leq n)$ に対 してinf $\left\{X_{j}, Y\right\} \succeq \inf \left\{X_{j}, \inf \left\{X_{i} \mid 1 \leq i \leq n\right\}\left(\sim \inf \left\{X_{i} \mid\right.\right.\right.$ $1 \leq i \leq n\})$ が成立する . ゆえに $X_{i}^{\prime} \succeq \inf \left\{X_{j} \mid 1 \leq j \leq\right.$ $n\}$ が成り立つ.また, $X_{i}^{\prime} \nsim \top, X_{i} \succeq X_{i}^{\prime}$ かつ $Y \sim \sup \left\{X_{i}^{\prime} \mid\right.$ $1 \leq i \leq n\}$ が成立し，ゆえに (2) が成立する .

\section{$4 \cdot 2$ 推論アルゴリズム}

本節では既存の論理プログラミングの手法を用いて， 定義 3 の具体化として協調的妥協に対して健全な推論ア ルゴリズムを与える . 論理プログラミングに対して新し い計算手法を与えることが目的ではないことに留意され たい，推論モデルを論理で具体化した推論アルゴリズム は，議論における論証の構築に使われる．論証か偝景知 識から構筑されることを想定して，背景知識に確定節集 合を持つことを許容する一般化包捸によってモデルを具 体化する．一般化包攝の詳細な定義は文献 [Buntine 88] を参照されたい，既知の事実として，一般化包捸は相対 伴意の近似であり，空の背景知識の下で包搨関係に帰着 される [Nienhuys-Cheng 97] .

$\mathcal{L}_{1}$ を有限個の定数と述語記号を持ち, 関数言号を持た ない確定節言語とする． $\mathcal{D} \subseteq \mathcal{L}_{1}$ を頭部に同じリテラル を持つ確定節集合， $\mathcal{B} \subseteq \mathcal{L}_{1}$ を有限の確定節集合，すなわ ち確定プログラム， $\geq_{\mathcal{B}}$ を $\mathcal{B}$ に関する一般化包捸とする このとき $\left\langle\mathcal{D}, \geq_{\mathcal{B}}>\right.$ は束である . $\left\langle\mathcal{D}, \geq_{\mathcal{B}}>\right.$ 上での推論 アルゴリズムを与える . アルゴリズムの入力は $\mathcal{B}, \mathcal{D}$, 及 び $X_{1}, \ldots, X_{n} \in \mathcal{D}$ ，包摂に関する精緻化作用素 $\rho_{L}$ の繰 り返し適用回数 $m$ とする.

$X, Y$ を節とする.$X \theta \subseteq Y$ を満たす $\theta$ か存在するとき， $X$ は $Y$ を包摂するといい, Algorithm 1 では $X \sqsupseteq Y$ と

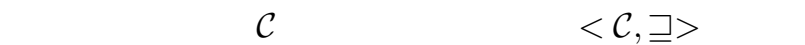
精緻化作用素を $\rho_{L}$ と表記する.$\rho_{L}$ の詳細な定義は文献 [Nienhuys-Cheng 97] を参照されたい， $\rho_{L}$ は節を引数に 取り，光の節が包摂する節の集合を返す関数であり，この 計算は引数の節に対して関数, 定数, 変数の代入, または 新しいリテラルの追加によって実現される . Algorithm 1 における $\rho_{L}^{m}$ は $\rho_{L}$ の出力の要素を引数として $\rho_{L}$ に渡す ことを $m$ 回繰り返すことを意味する . 確定節 $X$ に関して $X^{+}$は頭部を， $X^{-}$は本体部の集合を表し， $\bar{S}$ は集合 $S$ の元である論理式の否定からなる論理式集合を表すもの とする $. \alpha, \theta, \sigma_{i}, \varphi_{i}$ は乥れ光れ $\mathcal{B}$ に関する $Y$ のスコーレ ム代入， $\mathcal{B} \cup\{Y\}$ に関する $X_{1} \vee \cdots \vee X_{n}$ のスコーレム 代入， $\mathcal{B} \cup\left\{W_{i} \mid 1 \leq j \leq n\right\}$ に関する $W_{i}$ のスコーレム 代入， $\mathcal{B} \cup\left\{X_{j} \mid 1 \leq j \leq n\right\}$ に関する $X_{i}$ のスコーレム代

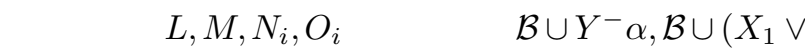
$\left.\cdots \vee X_{n}\right)^{-} \theta, \mathcal{B} \cup W_{i}^{-} \sigma_{i}, \mathcal{B} \cup X_{i}^{-} \phi_{i}$ の最小エルブランモ デルを表す . 煩雑さを避けるためこれらの計算はアルゴ リズムには陽に明記されない， $\mathcal{L}_{1} に$ 対する制約により有 限の最小エルブランモデルが存在し，产れは不動点オプ レータ $T_{p}[$ Emden 76] によって計算可能である . アルゴ リズムではこの結果を利用する . 


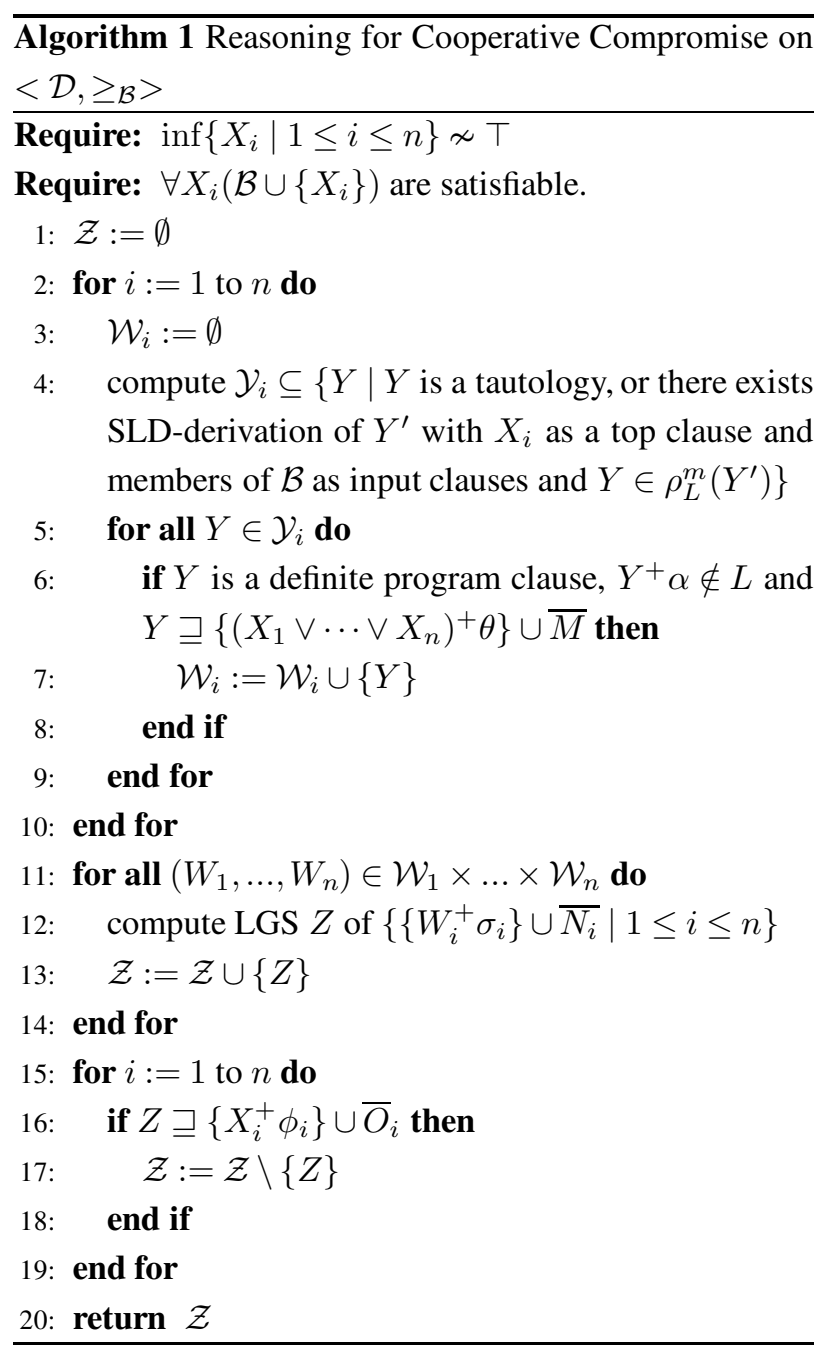

アルゴリズムの 2-10行目は $X_{i}$ から $X_{i} \geq_{\mathcal{B}} Y$ を満たす $Y$ の計算及び光の評価の局面である $. X, Y \in \mathcal{D}$ に対して $X \geq_{\mathcal{B}} Y$ が成立するときかつ弚のときに限り $X$ を頂上節， $\mathcal{B}$ の元を入力節とする $Y$ の $S L D$ 演繹が存在するという 命題 (Theorem 16.25 [Nienhuys-Cheng 97]) に基づき ,4 行目では $S L D$ 演繹により $Y$ か計算される.$S L D$ 演繹は $S L D$ 導出と包捸からなり，アルゴリズムには分割して記 述される，包捸の計算に関して，言語 $\mathcal{L}_{1}$ の制約により< $\mathcal{L}_{1}, \sqsupseteq>の 下$ 方精緻化作用素 $\rho_{L}$ は局所的有限性 (locally finiteness) を満たし (Theorem 17.15 [Nienhuys-Cheng 97]），ゆえに $\rho_{L}$ は計算可能である.5-9行目では $Y$ か確 定節であること，及び $T \Varangle_{\mathcal{B}} Y$ かつ $Y \geq_{\mathcal{B}} X_{1} \vee \cdots \vee X_{n}$ か評価される.ここでは $X, Y \in \mathcal{D}$ に対して $\mathcal{B} \cup X^{-} \sigma$ の 最小エルブランモデル $M$ が有限であるならば， $Y \geq_{\mathcal{B}} X$ のときかつ弚のときに限り $Y \sqsupseteq\left\{X^{+} \sigma\right\} \cup \bar{M}$ が成立する という命題 (Lemma 16.28 [Nienhuys-Cheng 97]) に基 づき，一般化包捸は決定可能な包捸に帰着される．一方 11-19 行目は任意の $W_{i}$ から $Z \geq_{\mathcal{B}} W_{i}$ を満たす $Z$ の計 算及び光の評価の局面である．12 行目では同じく包摂を 用いて $\left\{\left\{W_{i}^{+} \sigma_{i}\right\} \cup \overline{M_{i}} \mid 1 \leq i \leq n\right\}$ の包捸に基づく上限 (LGS) の計算によって間接的に $\left\{W_{i} \mid 1 \leq i \leq n\right\}$ の一般 化包捸に基づく上限が計算される．14-18 行目では任意
の $X_{i}$ に対して $Z \geq_{\mathcal{B}} X_{i}$ か評価される . これより次の命 題が成立する.

〈命題 2 $\rangle\left\langle\mathcal{D}, \geq_{\mathcal{B}}>\right.$ 上の推論アルゴリズムは $<\mathcal{D}, \geq_{\mathcal{B}}>$ 上の協調的妥協に関して健全である.

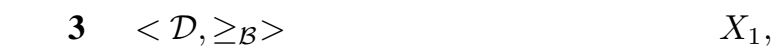
$X_{2}, \mathcal{B}$ を乥れ艺れ次式とする .

- $X_{1}=\operatorname{compact}(x) \wedge \operatorname{light}(x) \wedge \operatorname{camera}(x) \rightarrow \operatorname{buy}(x)$

- $X_{2}=\operatorname{resolution}(x$, high $) \wedge$ battery $(x$, long $) \wedge$ camera $(x) \rightarrow$ buy $(x)$

- $\mathcal{B}=\{\operatorname{compact}(x) \wedge \operatorname{light}(x) \rightarrow$ userFriendly $(x)\}$ 次の $Y_{1}, Y_{2}$ は光れ光れ $X_{1}, X_{2}$ から包捸される確定節で あり，ゆえに $S L D$ 演繹可能な式である .

- $Y_{1}=\operatorname{battery}(x, \operatorname{long}) \wedge \operatorname{compact}(x) \wedge \operatorname{light}(x) \wedge$ camera $(x) \rightarrow \operatorname{buy}(x)$

- $Y_{2}=$ userFriendly $(x) \wedge$ resolution $(x$, high $) \wedge$ battery $(x$, long $) \wedge \operatorname{camera}(x) \rightarrow \operatorname{buy}(x)$

下方精維化作用素 $\rho_{L}$ は $X_{1}$ に対してリテラル $\neg$ battery $(y, z)$ を追加し，代入 $\{y / x, z /$ long $\}$ を施すことで $Y_{1}$ を導出 し， $X_{2}$ に対してリテラル ᄀuserFriendly $(y, z)$ を追加 し，代入 $\{y / x\}$ を施すことで $Y_{2}$ を導出する $. L_{1}, L_{2}, M$ は光れ次式である。

- $L_{1}=\{$ battery $(a$, long $), \operatorname{compact}(a), \operatorname{light}(a)$, camera $(a)$, userFriendly $(a)\}$

- $L_{2}=\{$ userFriendly $(b)$, resolution $(b$, high $)$, battery (b,long), camera $(b)\}$

- $M=\{\operatorname{compact}(c), \operatorname{light}(c)$, user Friendly $(c)$, camera $(c)$, resolution(c, high), battery $(c$, long $)\}$

$Y_{1}, Y_{2}$ は Algorithm 1 の 6 行目の条件を満たす. $\sigma_{1}=$ $\{x / d\}, \sigma_{2}=\{x / e\}$ とするとき, $\mathcal{B} \cup Y_{i}^{-} \sigma_{i}$ の最小エルブ ランモデル $N_{i}$ は光れ次式である .

- $N_{1}=\{$ battery $(d$, long $)$, compact $(d), \operatorname{light}(d)$, camera $(d)$, user Friendly $(d)\}$

- $N_{2}=\{$ userFriendly $(e)$, resolution $(e$, high $)$, battery (e,long), camera $(e)\}$

このとき，次の $Z$ は $\left\{\left\{Y_{i}^{+} \sigma_{i}\right\} \cup \overline{N_{i}} \mid 1 \leq i \leq n\right\}$ の包捸 に基づく上限であり，従い $\left\{Y_{1}, Y_{2}\right\}$ の一般化包摂に基づ く上限である .

- $Z=$ userFriendly $(x) \wedge$ battery $(x$, long $) \wedge$ $\operatorname{camera}(x) \rightarrow \operatorname{buy}(x)$

15-19 行目の同樣の評価により $Z$ は推論結果となる.$X_{1}$ はコンパクトで軽いカメラであることを購入の十分条件 とし， $Z$ はバッテリの持ちが良いことを購入の必要条件 とする . 直観的には, バッテリの持ちの良さが購入の必 要条件となるという意味で $X_{1}$ における妥協が $Z$ に反映 されている . 同樣に , 使いやすさが購入の必要条件とな るという意味で $X_{2}$ における妥協が $Z$ に反映されている . 各 $X_{1}, X_{2}$ で示される購入の必要条件が削減されるという 意味で $X_{1}, X_{2}$ における妥協が $Z$ に反映されているわけ ではない，弚れゆえ，本例は日常での妥協という言葉の 持つ意味合いとは直観的に異なる推論であることに留意 
されたい、また，本稿ではある特定の協調的妥協ではな く推論の健全性と完全性の観点から多くの協調的妥協を 推論することを目的としている．言語バイアスや探索バ イアスなどを駆使することで特定の協調的妥協を推論す る能力を向上させることは可能であるが，光れは本稿で は対象とはしない，次章では例 3 の推論結果を利用する .

\section{5. 妥協を伴う議論}

前章までは，本章で定義かつ使用される論証の内部で 使われる推論に関する内容である . 本章では論証の相互 作用として推論の非単調性を実現する議論システムを示 し，提案した推論を組み込んだ論証か議論に基づく交渉 の妥協的解決に有効であることを例示する．

\section{$5 \cdot 1$ 議論システム}

知識表現言語には Reiter のデフォルト論理 [Reiter 80] の言語を採用する . 一階言語 $\mathcal{L}_{0}$ に対して , デフォルト 理論は $\mathcal{F}_{n} \cup \mathcal{F}_{c}$ が無矛盾である必然的知識 $\mathcal{F}_{n} \subseteq \mathcal{L}_{0}$ と 不確実知識 $\mathcal{F}_{c} \subseteq \mathcal{L}_{0}$, 及び次に定義される撤回可能規則 (defeasible rule) の集合 $\Delta$ の和集合 $\mathcal{F}_{c} \cup \mathcal{F}_{n} \cup \Delta$ であ る.デフォルト理論に基づく各種定義のうち, 本稿で必 要なものに限り [Prakken 97a] から抜粋する .

【定義 4】（撤回可能規則, DMP, 論証 [Prakken 97a]） $\varphi_{1}, \ldots, \varphi_{n}, \psi \in \mathcal{L}_{0}$ とする .

・撤回可能規則は次の形式を持つ.

$$
\varphi_{1} \wedge \cdots \wedge \varphi_{j} \wedge \sim \varphi_{j+1} \wedge \cdots \wedge \sim \varphi_{n} \Rightarrow \psi
$$

$\varphi_{1} \wedge \cdots \wedge \varphi_{j}$ を規則の前提,$\sim \varphi_{j+1} \wedge \cdots \wedge \sim \varphi_{n}$ を 規則の正当化（justification）， $\psi$ を規則の結論と呼 ぶ. . 正当化に現れる任意の $\varphi_{i}(j+1 \leq i \leq n)$ に対

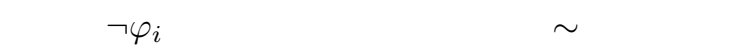
であることを仮定し，非形式的に〜 $\varphi$ は $\varphi \varphi$ は証明 できない」と読む．

・撤回可能モーダスポネンス $D M P$ は次の形式を持つ 推論規則である .

$\underline{\varphi_{1} \wedge \cdots \wedge \varphi_{j} \wedge \sim \varphi_{j+1} \wedge \cdots \wedge \sim \varphi_{n} \Rightarrow \psi \quad \varphi_{1} \wedge \cdots \wedge \varphi_{j}}$ $\psi$

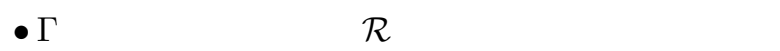
$\Gamma$ に基づく論証は次の条件を満たす，異なる一階の 論理式と撤回可能規則の基礎例の列 $\left[\varphi_{1}, \ldots, \varphi_{n}\right]$ であ る . 任意の $\varphi_{i}$ に対して，次のいずれかが成り立つ. ○ $\varphi_{i} \in \Gamma$

$\circ \psi_{1}, \ldots, \psi_{m} \in\left\{\varphi_{1}, \ldots, \varphi_{i-1}\right\}$ かつ $\psi_{1}, \ldots, \psi_{m} / \varphi_{i} \in \mathcal{R}$ 任意の論証 $A=\left[\varphi_{1}, \ldots, \varphi_{n}\right]$ に対して,$\varphi_{i} \in A$ が一階の 論理式であるとき关れを $A$ の結論といい，Aの結論から なる集合を $C O N C(A)$ と表記し，Aの撤回可能規則の仮 定であるとき $A$ の仮定といい， $A$ の仮定からなる集合を $A S S(A)$ と表記する . 本稿では $\varphi_{n}$ が一階の論理式である
とき乥れを $A$ の最終結論といい,$F C O N C(A)=\left\{\varphi_{n}\right\}$ と表記する．また， $A$ が非演繹的な推論を用いるとき， $A$ を撤回可能であるという。

【定義 5】（反駁と無効化） $A, B$ を異なる論証とする． $A=[]$ かつ $F C O N C(B) \cup \mathcal{F}_{n} \vdash \perp$ または次の条件が成 立するとき， $A$ は $B$ を反駁 (rebut) する .

(1) $C O N C(A) \cup \mathcal{F}_{n} \vdash \alpha$, かつ

(2) $C O N C(B) \cup \mathcal{F}_{n} \vdash \neg \alpha$, かつ

(3) $C O N C(B) \nsupseteq C O N C(A)$, かつ

(4) $B$ は撤回可能

また， $A=[], \alpha \in A S S(B)$ かつ $C O N C(B) \cup \mathcal{F}_{n} \vdash \neg \alpha$ または $\alpha \in A S S(B)$ かつ $C O N C(A) \cup \mathcal{F}_{n} \vdash \neg \alpha$ が成立 するとき， $A$ は $B$ を無効化 (undercut) する .

定義 5 に現れるトはすべて一階論理における構文論的 帰結関係を表す．反駁の条件 (1), (2) は必然的知識の下 で互いの論証の結論が矛盾することを意味する . 条件 (3) は反駁する側の論証の結論には反駁される側の論証の結 論には含まれてはいない論理式を含むことを意味し，条 件 (4) は $B$ は非演繹的な推論を含むことを意味する . 一 方，必然的知識の下で論証の結論が，自身のある仮定の 論理的否定を帰結するとき，弚の論証は空の論証によっ て無効化される．また，異なる論証 $A, B$ に対して，必然 的知識の下で $A$ の結論が $B$ のある仮定の論理的否定を 帰結するとき， $A$ は $B$ を無効化する．定義より，たとえ 必然的知識の下で論証 $A$ の結論が矛盾している（すなわ

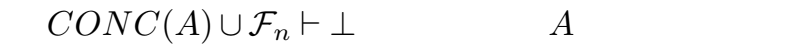
駁することはなく，また空である論証から反駁されると は限らない．これは反駁及び無効化は異なる論証間にお いて定義され, また必然的知識の下で最終結論が矛盾し ている（すなわち $F C O N C(A) \cup \mathcal{F}_{n} \vdash \perp ）$ 場合に限り $A$ は空である論証から反駁されることに起因する .

【定義 6】（打破 [Prakken 97a]） 次のいずれかの条件 が成立するとき, 論証 $A$ は論証 $B$ を打破 (defeat)する.

- $A$ は $B$ を無効化する .

- $A$ は $B$ を反駁し， $B$ は $A$ を無効化しない . 論証 $A, B$ に関して $A$ が $B$ を打破し， $B$ が $A$ を打破し ないとき $A$ は $B$ を完全に打破するという .

議論の対話的証明論 [Prakken 97b] に関するもののう ち本稿で必要なものだけを抜粋する。

【定義 7】（対話, 対話木, 勝利, 正当化 [Prakken 97b])

- 対話は次の条件を満たす有限かつ非空の手 $m_{\text {ove }}=$ $\left(\right.$ Player $_{i}$, Arg $\left._{i}\right)(i>0)$ の列である .

(1) $i$ が奇数ならば Player Pl $_{i}=P$ かつ $i$ が偶数な らば, Player $_{i}=O$ である .

(2) Player $_{i}=$ Player $_{j}=P$ かつ $i \neq j$ ならば, $\mathrm{Arg}_{i} \neq \mathrm{Arg}_{j}$ である .

(3) Player $_{i}=P(i>1)$ ならば , Arg $_{i}$ は Arg $_{i-1}$ を完全に打破する集合の包含関係に関して極小 の論証である .

(4) Player $_{i}=O$ ならば, $A r g_{i}$ は $A r g_{i-1}$ を打破 
する .

・対話木は次の条件を満たす手の有限の木である.

(1) 木の根から葉への各経路は対話である .

(2) Player $_{i}=P$ ならば, move $_{i}$ の子は $\mathrm{Arg}_{i}$ を 打破する全ての論証からなる .

• Player $_{j}$ が手を出すことをできないとき, Player $_{i}(i$ $\neq j)$ は対話に勝利する . また , 対話木の根から葉 のすべての経路の対話に Player $i$ が勝利するとき， Player $_{i}$ は対話木に勝利する .

- $A$ を論証とする . $A$ を根に持つ対話木が存在し，か つ対話木に提案者か勝利するとき， $A$ は証明可能的 に正当化 (provably justified) される.

さらに正当化論証に対する意味論的定義力存在し [Dung 95] , 任意の証明可能的に正当化される論証は意味論的に も正当化されることが知られている [Prakken 97b] .

\section{$5 \cdot 2$ 妥協を伴う議論例}

議論では任意のエージェント $\operatorname{Agent}_{i}(i=1,2)$ はデフォ ルト理論 $\Gamma_{i}$ を持ち，理論は議論の過程で変化しないこと を仮定する . 各 Agent $_{i}$ は $\Gamma_{i}$ の要素または $\operatorname{Agent}_{j}(j \neq i)$ が提示した論証の要素を用いて論証を構築する. . 光して 対話木を形成することで根にある論証の正当性を評価す る.議論例では, どの知識に対して妥協するか, 議論の どの局面で妥協するかの指針は与えていない . この詳細 は今後の課題である .

$\S 1$ 規則に対する協調的妥協

各 Agent $_{i}$ は次のデフォルト理論 $\Gamma_{i}=\mathcal{F}_{n}^{i} \cup \mathcal{F}_{c}^{i} \cup \Delta^{i}$ を持つとする .

$\mathcal{F}_{n}^{1}=\{\operatorname{camera}(a)$, camera $(c)$, overBudget $(b)$,

$\operatorname{compact}(x) \wedge \operatorname{light}(x) \wedge \operatorname{camera}(x) \rightarrow \operatorname{buy}(x)\left(=X_{1}\right)$, overBudget $(x) \rightarrow \neg$ buy $(x)$, takeShoot $(b, 200)\}$

$\mathcal{F}_{c}^{1}=\{\operatorname{compact}(a)$, userFriendly $(c)$, battery $(c$, long $)$, $\operatorname{compact}(x) \wedge \operatorname{light}(x) \rightarrow$ userFriendly $(x)\left(=r_{3}\right)$, takeShoot $(x, y) \wedge>(300, y) \rightarrow \neg$ battery $(x$, long $)$ $\left.\left(=r_{5}\right)\right\}$

$\Delta^{1}=\left\{\sim \neg \operatorname{light}(a) \Rightarrow \operatorname{light}(a)\left(=r_{1}\right)\right\}$

$\mathcal{F}_{n}^{2}=\{\operatorname{camera}(b), \neg$ inStock $(a)$, resolution $(x$, high $) \wedge$

battery $(x$, long $) \wedge \operatorname{camera}(x) \rightarrow \operatorname{buy}(x)\left(=X_{2}\right)$,

$\neg$ inStock $(x) \rightarrow \neg$ buy $(x), \operatorname{price}(b, \$ 200)$,

$\operatorname{price}(x, y) \wedge \geq(\$ 300, y) \rightarrow$ withinBudget $\left.(x)\left(=r_{4}\right)\right\}$

$\mathcal{F}_{c}^{2}=\{$ resolution $(b$, high $)\}$

$\Delta^{2}=\left\{\sim \neg\right.$ battery $(b$, long $) \Rightarrow$ battery $(b$, long $\left.)\left(=r_{2}\right)\right\}$

議論には次式で表される議題が存在し，任意の対話木の 根の論証 $A$ に対して $C O N C(A) \supseteq I s s u e \theta$ を満たす代 入 $\theta$ が存在しなければならないとする .

- Issue $=\{\operatorname{buy}(x), \operatorname{camera}(x)\}$

論証の構築には，任意の演繹的推論, $D M P,<\mathcal{D}, \geq_{\mathcal{B}}>$ 上の協調的妥協に対する推論を使うことができるとする . 以下では論証で使用される推論を可視化する目的で論証 を証明木形式で記述する . 演繹的推論を「一」, DMP

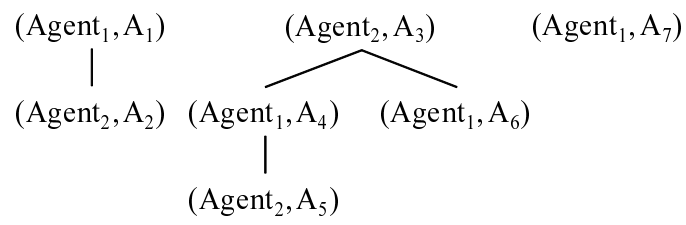

図 3 対話木

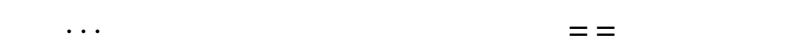
の論証 $A_{1}, A_{2}$ は午れ光れ $\Gamma_{1}, \Gamma_{2}$ から生成可能な論証で あり，図 3 の左端の対話木を構成する .

$$
\begin{aligned}
& A_{1}: \frac{\not \operatorname{light}(a) \quad \operatorname{compact}(a) \quad \operatorname{cam}(a) \quad X_{1}}{\operatorname{buy}(a)} \\
& A_{2}: \frac{\neg i n \operatorname{Stock}(a) \quad \neg \operatorname{inStock}(x) \rightarrow \neg b u y(x)}{\neg b u y(a)}
\end{aligned}
$$

次の論証 $A_{4}, A_{6}$ は $\Gamma_{1}$ から， $A_{3}, A_{5}$ は $\Gamma_{2}$ から生成可能 な論証であり，図 3 の中央の対話木を構成する .

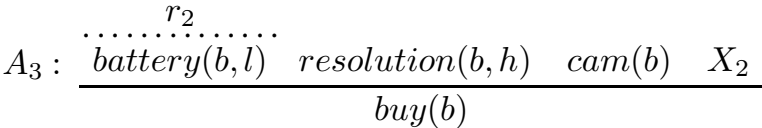

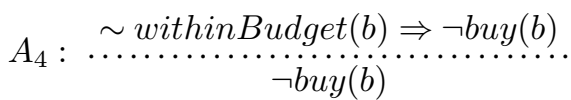

$$
\begin{aligned}
& A_{5}: \frac{\operatorname{price}(b, \$ 200) \quad \geq(\$ 300, \$ 200) \quad r_{4}}{\text { withinBudget }(b)} \\
& A_{6}: \frac{\text { takeShoot }(b, 200) \quad>(300,200) \quad r_{5}}{\neg \text { battery }(b, \text { long })}
\end{aligned}
$$

次の論証 $A_{7}$ は $\Gamma_{1}$ と $A_{3}$ で使われた $X_{2}$ から生成可能な 論証である . 図 3 の右端の対話木を構成する .

$$
A_{7}: \stackrel{X_{1}}{=}=\frac{X_{2}=\stackrel{r_{3}}{=}=}{\ln }=\frac{\operatorname{user} F(c) \text { battery }(c, l) \operatorname{cam}(c)}{\operatorname{buy}(c)}
$$

$X_{1}, X_{2}, Z$ は例 3 と同じものである . $A_{7}$ は証明可能的に 正当化論証である . $\Gamma_{1} \cup \Gamma_{2}$ から $b u y(c)$ を結論に持つ論 証は演繹的には構筑できないことに留意されたい .

$\S 2$ 最終結論に対する協調的妥協

目的から手段を決定する推論は実践的推論と呼ばれ， 一般にアブダクティブな形式を持つ [Walton 08] . 次の例 では言語が実践的であることを非形式的に仮定し，原子 式 $A$ を $\left\ulcorner A\right.$ 実現される」と読むことにする . 各 $A_{\text {d }}$ ent $t_{i}$ の願望を $\mathcal{D}^{i} \subseteq \mathcal{F}_{n}^{i}$ で表す . 各 Agent $_{i}$ は次のデフォルト 理論を持つとする . $\mathcal{F}_{n}^{1}=\mathcal{D}^{1}=\{$ buyClothes, seeMovie $\}$ $\mathcal{F}_{c}^{1}=\{$ goShopping $\rightarrow$ buyClothes $(=S \rightarrow C l)$,

goCinema $\rightarrow$ seeMovie $(=C i \rightarrow M)\}$

$\mathcal{F}_{n}^{2}=\mathcal{D}^{2}=\{$ saveMoney, haveDinner $\}$

$\mathcal{F}_{c}^{2}=\{$ goShopping $\rightarrow \neg$ saveMoney $(=S \rightarrow \neg M)$,

goRestaurant $\rightarrow$ haveDinner $(=R \rightarrow D)\}$

論証の構築には任意の演繹的推論，アブダクティブな推 論 , $<\mathcal{L}, \mid=>$ 上の協調的妥協に対する推論を使えるもの 
とし，アブダクティブな推論を「-・-」で表記する．次の 論証 $A_{1}, A_{2}$ は光れ光れ $\Gamma_{1}, \Gamma_{2}$ から生成可能である.

$$
\begin{aligned}
& A_{1}: \frac{C l}{-\frac{S}{S} \longrightarrow-\underline{l}-\underline{M}-\frac{C i}{C i} \vec{i}}-\frac{M}{S \wedge C i}
\end{aligned}
$$

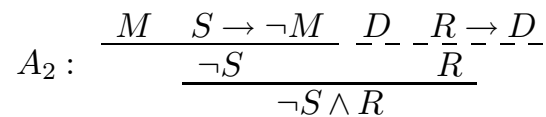

次の論証 $A_{3}$ は証明可能的に正当化される論証である.

$$
A_{3}: \quad \stackrel{A_{1}}{=}=\stackrel{A_{2}}{\bar{C}} i \wedge
$$

$A_{3}$ の結論は $A_{1}$ の結論と $A_{2}$ の結論から演繹可能でも ある．しかし，これは爆発原理に因るものであり，全論 理式の中の一つに過ぎない，一方，提案した推論はある 統一的基準の下で矛盾からの合理的推論の在り方を与え る. $S \wedge R, T \wedge \neg S$ のいずれも $A_{1}, A_{2}$ から提案した推論 によっては導出できず，また $A_{1}, A_{2}$ のいずれも $A_{3}$ を打 破できないことに留意されたい .

\section{6. 関 連 研 究}

本章では提案した協調的妥協に対する推論と種々の推 論の型及び，既存の議論研究を対比する．

\section{1 他の推 論 方式}

協調的妥協に対する推論と比較するときの帰納推論の 特徵は仮説が事後十分性を満たすことである．すなわち， 任意の仮説はすべての正例を説明する．これに対して，提 案した推論か浗める仮説は定義 1 , 定義 2 の不十分性に あるように, 各正例を説明しない。この十分性と不十分 性の関係はアブダクションとの間にも同樣に成り立つ.

提案した推論の結論は必ずしも演繹的に導出されると は限らないという点で演繹推論とも異なる . 例えば，例 3 では， $Z$ は $X_{1}, X_{2}$ の間の協調的妥協であるが $\mathcal{B}, X_{1}, X_{2}$ からの意味論的帰結ではない．これは提案した推論及び 協調的妥協力抽象的な束に対して与えられることに起因 している．ただし，もし束の順序関係を充足関係とする 場合には任意の協調的妥協は前提からの意味論的帰結と なる．しかし，この結果があるとしても協調的妥協に対 する推論は重要であると考える．なぜなら，古典論理， 樣相論理などの爆発原理を有する体系における演繹的推 論は矛盾からすべての論理式か導出されるという意味に おいて，矛盾からの合理的な推論には関心を持たない . 弚れに対して $<\mathcal{L}, \vDash>$ 上の協調的妥協に対する推論は $\left\{X_{i} \in \mathcal{L} \mid 1 \leq i \leq n\right\}$ が矛盾する状況において各 $X_{i}$ が充 足可能であるという条件下で，矛盾 $\left\{X_{i} \mid 1 \leq i \leq n\right\}$ か らの合理的推論を可能とする . このことは定義 3 の条件 (1)により $\left\{X_{i} \mid 1 \leq i \leq n\right\}$ ではなく，各 $X_{i}$ が演繹の仮 定となることが保証され，また (2)より $X_{i}$ からの演繹 $Y_{i}$ に対して， $Y_{1} \wedge \cdots \wedge Y_{n}$ の計算が行われることに起因 する . 例 2 は提案した推論による合理的な推論結果の一 例である。

\section{$6 \cdot 2$ 他の議 論 研 究}

[Sawamura 03] はへーゲルの弁証法といわれるものの うち矛盾の許容, 否定の否定の法則を形式的論理として 捉えることを試みた弁証法論理 DL, DM [Routley 76] に 対して, 次の 7 つの弁証法的推論規則を導入している.

1. $A, \neg A \Rightarrow A$

2. $A, \neg A \Rightarrow \neg A$

3. $A \wedge B, \neg B \Rightarrow A$

4. $A \wedge B, \neg B \Rightarrow B$

5. $A \wedge B, \neg B \Rightarrow A \wedge \neg B$

6. $A \wedge \neg B, \neg A \wedge B \Rightarrow A \wedge B$

7. $A(a), \neg A(a) \Rightarrow A(a) \wedge \neg A(b)$

DL, DM は爆発原理を有さないので矛盾からすべての論 理式か導出されることはなく, 7 つ推論規則は譲歩や 妥協として矛盾からの推論を形式論理において実現して いる.しかし，7 つの推論規則は光れを支配する統一的 な基準が示されておらず，また推論の前提か論理的矛盾 に限定されるという欠点を持つ.これに対して本稿は抽 象的な束の上に統一的基準の下で推論モデル及び妥協を 定義しており，また哲学的知見 [Sabre 91] に基づき，推 論の前提を論理的矛盾に限定せず，ある条件を満たす任 意の論理式とする . 例 3 は兴の一例である . 一方 , 提案 した推論モデルは 7 つの推論規則のうち，3 しか推論す る能力を持たない．これは $1,2,5,7$ に関しては，これら が讓歩を推論目的とするため，妥協を対象とする本稿で は対象外であることに起因し，4 に関しては，光の推論 結果が定義 2 で課せられる関連性を満たさないこと，6 に関しては，光の推論結果が妥協であるが，協調性を満 たさないことに起因する．しかし，5.2 節の最終結論の 協調的妥協にみられるように提案した推論は 7 つの推論 規則が導出できない論理式を導出する．

[Amgoud 08] は議論に基づく交渉の抽象的な形式化を 与え，交渉に重要な概念として「譲歩」を導入している ここでの讓歩は，所与の提案のうち議論によって準最適 とみなされた提案を指すものであり，提案した推論か対 象とするような推論によって導出されるものではない．ま た [Bench-Capon 06] は実践的三段論法を論証に組み込 んでいる.ここでは自身の目的から弚れを実現する最適 な手段を明らかにすることが狙いであり，妥協といった 概念は扱われていない .

\section{7. 結論と 今後の課題}

我々は妥協及び協調的妥協を抽象的な束の上に定義し， 協調的妥協に対して健全かつ完全な推論モデルを示した . そして推論モデルの具体化として確定節言語と一般化包 摂を対象に協調的妥協に関して健全な推論アルゴリズム を定義した .また，定義した議論システムの下で提案し た推論力議論の対立の解決に有効であることを例示した 。 提案した推論アルゴリズムでは種々のバイアスを扱っ 
ていない . 帰納推論で与えられる探索バイアスや言語バ イアスによってアルゴリズムを実際的な問題へ適用可能 なものに詳細化する必要がある．また近年，種々の推論を 論証に組み込むことが行われている [Bench-Capon 06] . しかし，本稿を含めて議論の局面と使用する推論の関係 に触れているものは少ない．特に，本稿が対象とした妥 協などは合意形成の最終局面で扱われるべきである．今 後, 議論の適切な局面での適切な推論の扱いを可能にし ていく必要がある.他方, Dung の抽象的議論フレーム ワーク [Dung 95]や Prakken の対話 [Prakken 97b] を拡 張することも今後の課題である . 現状では妥協は論証構 築に使われる一つの推論であり，論証に対する返答の手 段ではない．打破と妥協という手段が存在するときに議 論の結論がどのように決定されるのかについて今後 , 意 味論的かつ構文論的に考察していく計画である .

\section{$\diamond$ 参 考 文 献 $\diamond$}

[Amgoud 08] Amgoud, L., Dimopoulos, Y., and Moraitis, P.: A General Framework for Argumentation-Based Negotiation, in Proc. of The 4th International Workshop on Argumentation in Multi-Agent Systems (ArgMAS 2007), pp. 1-17 (2008)

[Bench-Capon 06] Bench-Capon, T. J. M. and Prakken, H.: Justifying Actions by Accruing Arguments, in Proc. of The First International Conference on Computational Models of Argument (COMMA 2006), pp. 247-258 (2006)

[Buntine 88] Buntine, W.: Generalized Subsumption and Its Applications to Induction and Redundancy, Artificial Intelligence, Vol. 36, pp. 146-176 (1988)

[Carnielli 07] Carnielli, W., Coniglio, M. E., and Marcos, J.: Logics of Formal Inconsistency, Vol. 14, pp. 1-93, Springer, handbook of philosophical logic, 2nd edition (2007)

[Dung 95] Dung, P. M.: On the acceptability of arguments and its funedamental role in nonmonotonic reasoning, logic programming, and $n$-person games, Artificial Intelligence, Vol. 77, pp. 321-357 (1995)

[Dung 08] Dung, P. M., Thang, P. M., and Toni, F.: Towards argumentation-based contract negotiation, in Proc. of The Second International Conference on Computational Models of Argument (COMMA 2008), pp. 134-146 (2008)

[Emden 76] Emden, M. H. V. and Kowalski, R. A.: The Semantics of Predicate Logic as a Programming Language, Journal of the Association for Computing Machinery, Vol. 23, pp. 733-742 (1976)

[Kowalski 94] Kowalski, R. A. and Toni, F.: Argument and Reconciliation, in Proc. of The Fifth Generation Computer Systems Workshop on Application of Logic Programming to Legal Reasoning, pp. 9-16 (1994)

[Mitroff 82] Mitroff, I. I. and Mason, R. O.: On the structure of dialectical reasoning in the social and policy sciences, Theory and Decision, Vol. 14, No. 4, pp. 331-350 (1982)

[Modgil 09] Modgil, S. and Luck, M.: Argumentation Based Resolution of Conflicts between Desires and Normative Goals, in Proc. of The Fifth International Workshop on Argumentation in Multi-Agent Systems (ArgMAS 2009), pp. 19-36 (2009)

[Nienhuys-Cheng 97] Nienhuys-Cheng, S.-H. and Wolf, de R.: Foundation of Inductive Logic Programming, Springer (1997)

[Nisbett 03] Nisbett, R. E.: The Geography of Thought: How Asians and Westerners Think Differently ... and Why, FREE PRESS (2003)

[Prakken 97a] Prakken, H.: Logical Tools for Modelling Legal Argument: A Study of Defeasible Reasoning in Law, Kluwer Academic Publishers (1997)

[Prakken 97b] Prakken, H. and Sartor, G.: Argument-based extended logic programming with defeasible priorities, Journal of Applied Non-classical Logics, Vol. 7, pp. 25-75 (1997)

[Rahwan 05] Rahwan, I., Sonenberg, L., and McBurney, P.: Bargain- ing and Argument-based Negotiation: Some Preliminary Comparions, in Proc. of The First International Workshop on Argumentation in Multi-Agent Systems (ArgMAS 2004), pp. 176-191 (2005)

[Reiter 80] Reiter, R.: A Logic for Default Reasoning, Artificial Intelligence, Vol. 13, pp. 81-132 (1980)

[Routley 76] Routley, R. and Meyer, R. K.: Dialectical logic, classical logic, and the consistency of the world, Studies in East European Thought, Vol. 16, No. 1-2, pp. 1-25 (1976)

[Sabre 91] Sabre, R. M.: An alternative logical framework for dialectical reasoning in the social and policy sciences, Theory and Decision, Vol. 30, No. 3, pp. 187-211 (1991)

[Sawamura 03] Sawamura, H., Yamashita, M., and Umeda, Y.: Applying Dialectic Agents to Argumentation in E-Commerce, Electronic Commerce Research, Vol. 3, No. 3-4, pp. 297-313 (2003)

[Thomas 92] Thomas, K. W.: Conflict and conflict management: Reflections and update, Journal of Organizational Behavior, Vol. 13, pp. 265-274 (1992)

[Walton 08] Walton, D.: Witness Testimony Evidence: Argumentation, Artificial Intelligence, and Law, Cambridge University Press (2008)

[Wells 06] Wells, S. and Reed, C.: Knowing When To Bargain, in Proc. of The First International Conference on Computational Models of Argument (COMMA 2006), pp. 235-246 (2006)

\section{〔担当委員 : 桜井 成一朗〕}

2010 年 3 月 25 日 受理

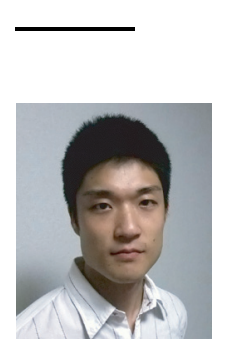

者 紹 介

\section{木藤 浩之(学生会員)}

2005 年新潟大学工学部情報工学科卒業. 2007 年北海道大 学大学院情報科学研究科コンピュータサイエンス専攻修士 課程修了.2007-2008 年三菱電機株式会社情報技術総合研 究所勤務 .ネットワークシステムに関する研究開発に従事。 2008 年東京工業大学大学院総合理工学研究科知能システ 么科学専攻博士課程入学. 現在に至る. 非演繹的推論, 数 理議論学, ゲーム理論の研究に従事し, マルチェージェン トシステム,セマンティックウェブへの展開に興味を持つ

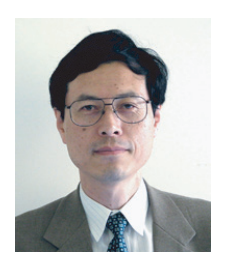

\section{栗原 正仁(正会員)}

1978 年北海道大学工学部電気工学科卒業. 1980 年同大学 院工学研究科情報工学専攻修士課程修了. 同年, 北海道大 学助手. 弚の後, 講師、助教授、および北海道工業大学教授 を経て, 2002 年北海道大学大学院工学研究科コンピュータ サイエンス専攻教授、現在, 同大学院情報科学研究科複合 情報学専攻教授. 工学博士.人工知能およびソフトウェア 科学の研究に従事. 情報処理学会, 電子情報通信学会, 日 本ソフトウェア科学会, 日本知能情報ファジィ学会各会員 .

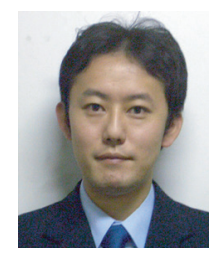

\section{片上 大輔(正会員)}

2002 年東京工業大学大学院博士後期課程修了. 博士 ( 工 学). 同年東京工業大学大学院総合理工学研究科助手. 2006 年ハートフォードシャー大学客員研究員およびチューリヒ 大学客員研究員. 2007 年東京工業大学大学院総合理工学 研究科助教. 2010 年東京工芸大学工学部准教授 . 現在に 至る・ヒューマンェージェントインタラクションに関する 研究に従事し,知的エージェントを用いた集団適応ならび 会, IEEE 各会員 に関係性の可視化に興味を持つ.日本知能情報ファジィ学

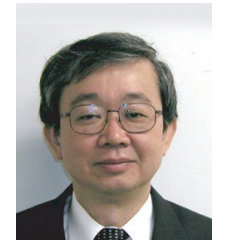

\section{新田 克己(正会員)}

1975 年東京工業大学工学部電子工学科卒業. 1977 年, 1980 年, 同大学院修士課程と博士課程を弚れ光れ修了.1980 年電子技術総合研究所に入所. 1989 年から 1993 年まで (財) 新世代コンピュータ技術開発機構に出向.1996 年東 京工業大学大学院総合理工学研究科教授, 現在に至る. 工 学博士.法的推論システム, ヒューマンインタフェース, マルチェージェントシステムなどの研究に従事 . 情報処理 学会, 電子情報通信学会, ヒューマンインタフェース学会, 言語処理学会, 情報ネットワーク法学会, IEEE 各会員. 